\title{
Metabolic engineering of Cupriavidus necator for heterotrophic and autotrophic alka(e)ne production
}

\author{
Lucie Crépin, Eric Lombard, Stéphane E Guillouet* \\ LISBP, Université de Toulouse, CNRS, INRA, INSA, 135 Avenue de Rangueil, 31077 Toulouse CEDEX 04, France
}

\section{A R T I C L E I N F O}

\section{Article history:}

Received 18 March 2016

Received in revised form

15 April 2016

Accepted 5 May 2016

Available online 20 May 2016

\section{Keywords:}

Cupriavidus necator

Alkane

Alkene

Hydrocarbon

Biofuels

Metabolic engineering

Fermentation

\begin{abstract}
A B S T R A C T
Alkanes of defined carbon chain lengths can serve as alternatives to petroleum-based fuels. Recently, microbial pathways of alkane biosynthesis have been identified and enabled the production of alkanes in non-native producing microorganisms using metabolic engineering strategies. The chemoautotrophic bacterium Cupriavidus necator has great potential for producing chemicals from $\mathrm{CO}_{2}$ : it is known to have one of the highest growth rate among natural autotrophic bacteria and under nutrient imbalance it directs most of its carbon flux to the synthesis of the acetyl-CoA derived polymer, polyhydroxybutyrate (PHB), (up to $80 \%$ of intracellular content). Alkane synthesis pathway from Synechococcus elongatus (2 genes coding an acyl-ACP reductase and an aldehyde deformylating oxygenase) was heterologously expressed in a C. necator mutant strain deficient in the PHB synthesis pathway. Under heterotrophic condition on fructose we showed that under nitrogen limitation, in presence of an organic phase (decane), the strain produced up to $670 \mathrm{mg} / \mathrm{L}$ total hydrocarbons containing $435 \mathrm{mg} / \mathrm{l}$ of alkanes consisting of $286 \mathrm{mg} / \mathrm{l}$ of pentadecane, $131 \mathrm{mg} / \mathrm{l}$ of heptadecene, $18 \mathrm{mg} / \mathrm{l}$ of heptadecane, and $236 \mathrm{mg} / \mathrm{l}$ of hexadecanal. We report here the highest level of alka(e)nes production by an engineered $C$. necator to date. We also demonstrated the first reported alka(e)nes production by a non-native alkane producer from $\mathrm{CO}_{2}$ as the sole carbon source.
\end{abstract}

๑ 2016 International Metabolic Engineering Society. Published by Elsevier Inc. All rights reserved.

\section{Introduction}

Increasing concerns about limited fossil fuels have stimulated interest in microbial production of biofuel from renewable carbon sources. Biofuels must be both compatible with existing liquid fuel infrastructure and produced at a competitive level for industrial production. Alkanes and alkenes are the predominant constituents of gasoline, diesel and jet fuels (Peralta-Yahya et al., 2012). Alka(e) nes synthesis have been reported in several microorganisms including cyanobacteria, bacteria, yeast and fungi (Ladygina et al., 2006). So far there have been several reported pathways for engineering alkane and alkene production derived from the fatty acid metabolism. Progress in metabolic engineering and identification of these pathways enabled biofuels production in native and non-native biofuel producing microorganisms (Beller et al., 2015; Wang and Lu, 2013).

\footnotetext{
Abbreviations: C. necator, Cupriavidus necator; S. elongatus, Synechococcus elongatus; E. coli, Escherichia coli; AAR, acyl-ACP reductase; ADO, aldehyde deformylating oxygenase; PHA, polyhydroxyalkanoates; $\mathrm{PHB}$, polyhydroxybutyrate; RBS, ribosome-binding site

* Corresponding author.

E-mail addresses: crepin@insa-toulouse.fr (L. Crépin) elombard@insa-toulouse.fr (E. Lombard), stephane.guillouet@insa-toulouse.fr (S. Guillouet).
}

In cyanobacteria alkane biosynthetic pathway is composed by 2 enzymes an acyl-ACP reductase (AAR, EC:1.2.1.80) and an aldehyde deformylating oxygenase (ADO, EC:4.1.99.5) (Li et al., 2012; Schirmer et al., 2010; Warui et al., 2011). AAR catalyzes the NADPH-dependent reduction of acyl-ACP or acyl-CoA into corresponding fatty aldehyde. Because it appears that aar has a higher affinity for acyl-ACP, this enzyme was named acyl-ACP reductase (Schirmer et al., 2010). ADO transforms $C_{n}$ fatty aldehyde to a $C_{n-1}$ alka(e)ne with the same degree of unsaturation as the parent substrate and C1-derived formic acid. ADO activity needs oxygen, $\mathrm{NADPH}$ and the auxiliary reducing system ferredoxin and ferredoxin reductase (N. Li et al., 2012; Warui et al., 2011).

Heterologous expression into Escherichia coli of these two genes from Nostoc punctiforme PCC73102 allowed alka(e)ne production up to $300 \mathrm{mg} / \mathrm{l}$ (primarily C15 alkane and C17 alkene) with more than $80 \%$ of the hydrocarbons found outside of the cells (Schirmer et al., 2010). Alka(e)ne content in Synechocystis sp. PCC6803 mutants overexpressing native alkane biosynthetic genes was $1.1 \%$ of dry weight cell and alka(e)ne production in photobioreactor reached $26 \mathrm{mg} / \mathrm{l}$ in 10 days (Wang et al., 2013). In Synechococcus sp. PCC 7002, overexpressing a heterologous alkane pathway allowed to reach $5 \%$ of cell dry weight (CDW) of alka(e)ne (Reppas and Ridley, 2010). Alka(e)ne production was also obtained in Saccharomyces cerevisiae and Cupriavidus necator mutant strains 
expressing a heterologous alkane pathway from Synechococcus elongatus (Bi et al., 2013; Buijs et al., 2015). In S. cerevisae mutant strain the biosynthesis was $2.7 \mu \mathrm{g} / \mathrm{g}_{\mathrm{CDW}}$ of heptadecane. And in $C$. necator around $6 \mathrm{mg} / \mathrm{l}$ of a mixture of pentadecane and heptadecene was produced. So far the highest reported titer of $580 \mathrm{mg} / \mathrm{l}$ of alka(e)ne was obtained with an engineered $E$. coli strain producing short chain fatty acids. In this work the authors overexpressed similar pathway with alternative enzymes, an acyl-CoA reductase (acr) from Clostridium acetobutylicum and a fatty aldehyde decarbonylase (CER1) from Arabidopsis thaliana (Choi and Lee, 2013). Lately, a wide range of short chain alka(e)nes from C3 to C10 was successfully produced from engineered E.coli (Sheppard et al., 2015).

Recently, Cupriavidus necator has been identified as a potential candidate for biofuel production from carbon dioxide $\left(\mathrm{CO}_{2}\right)$. This facultative chemolithoautotrophic bacterium is long known as capable of using $\mathrm{CO}_{2}$ and $\mathrm{H}_{2}$ as carbon and energy sources respectively (Pohlmann et al., 2006; Schuster and Schlegel, 1967). Under nutrient limitation in excess of carbon, $C$. necator redirected carbon flux toward polyhydroxyalkanoates (PHA) (mainly polyhydroxybutyrate (PHB)) as carbon storage material up to $80 \%$ of its cell dry weight (CDW) (Grousseau et al., 2013). Under autotrophic growth condition on $\mathrm{H}_{2} / \mathrm{CO}_{2} / \mathrm{O}_{2}, C$. necator was reported to produce $62 \mathrm{~g} / \mathrm{l}$ of PHB in $40 \mathrm{~h}$ (Tanaka et al., 1995). Because of PHB is a biobased and biodegradable polymeric material that can be an interesting substitute to petroleum derived plastics $C$. necator has been extensively studied for modeling PHB production from $\mathrm{CO}_{2}$ (Islam Mozumder et al., 2015) and industrially exploited in the production of biodegradable plastic for more than a decade (Chen, 2009). While, most efforts to engineer $C$. necator have focused on the bioplastics production (Insomphun et al., 2015, 2014) recently, it has been shown that $C$. necator can be used as a bioproduction platform of valuable molecules such as short-chain alcohols and fatty acids related compounds (Bi et al., 2013; Chen et al., 2015; Grousseau et al., 2014; Li et al., 2012; Lu et al., 2012; Müller et al., 2013; Torella et al., 2015).

C. necator strain was engineered for the biosynthesis of isobutanol and 3-methyl-1-butanol via branched amino-acid biosynthesis and Ehrlich pathway previously described in E. coli (Atsumi et al., 2010, 2008). Under semicontinuous flask cultivation on fructose $C$. necator mutant produced more than $14 \mathrm{~g} / \mathrm{l}$ of isobutanol in 50 days (Lu et al., 2012). $140 \mathrm{mg} / \mathrm{l}$ isobutanol were achieved with electricity and $\mathrm{CO}_{2}$ as the sole sources of energy and carbon, respectively (Li et al., 2012). A synthetic production pathway was rationally designed through codon and gene level optimization and expressed into $C$. necator mutant unable to produced PHB in order to efficiently divert carbon flux from PHB to isopropanol production (Grousseau et al., 2014). This C. necator mutant was able to achieve $3.44 \mathrm{~g} / \mathrm{l}$ of isopropanol with less than $1 \mathrm{~g} / \mathrm{l}$ of dry weight cells in batch culture on fructose representing the highest specific productivity of $C$. necator (Grousseau et al., 2014). Using $\mathrm{H}_{2}$ from water splitting to reduce carbon $\mathrm{CO}_{2}$, Torella and coworkers demonstrated isopropanol production up to $216 \mathrm{mg} / \mathrm{l}$ with a $C$. necator mutant strain from Grousseau's work (Torella et al., 2015).

Recent efforts to produce fatty acids and fatty acid-related chemicals in $C$. necator include the successful production of longchain fatty acids and methyl ketones (Müller et al., 2013). Engineering $C$. necator strain overexpressing a cytoplasmic version of the 'TesA thioesterase can afford production of free fatty acid with maximum titer of $0.017 \mathrm{mg} / \mathrm{l}$ in $2 \%$ fructose minimal medium and $10 \mathrm{mg} / \mathrm{l}$ in LB medium. In engineered $C$. necator strain deleted of two $\beta$-oxidation operons and expressing three heterologous genes (the acyl coenzyme A oxidase gene from Micrococcus luteus and fadB and fadM from E. coli) led to the production of $50-65 \mathrm{mg} / \mathrm{l}$ of diesel-range methyl ketones under heterotrophic growth conditions and $65-180 \mathrm{mg} / \mathrm{l}$ under autotrophic growth conditions
(Müller et al., 2013). Engineering C. necator strain for medium chain fatty acids (MCFA) production was constructed in a mutant unable to produced PHB, deleted for one of several acyl-CoA synthase, the first enzyme of $\beta$-oxidation and expressing a medium-chain-length-specific acyl-ACP thioesterase from Umbellularia californica UcFatB2. This mutant was reported to produced up to $60 \mathrm{mg} / \mathrm{l} \mathrm{MCFA}$ on fructose (Chen et al., 2015). Bi et al. reported the development of a genetic toolbox for the metabolic engineering of C. necator. The usefulness of this toolbox was further demonstrated by performing an optimization of hydrocarbon production in C. necator resulting in $6 \mathrm{mg} / \mathrm{l}$ of alka(e)ne production on fructose (Bi et al., 2013). All together these works demonstrated that $C$. necator is a good candidate for biofuel and chemicals productions from $\mathrm{CO}_{2}$.

In this work, we designed a synthetic production pathway through codon, gene copy number and gene level optimization in order to efficiently redirect the carbon flow from PHB toward alka (e)nes production. The resulting strain constructed Re2061-pLC10 was characterized in term of alka(e)nes and fatty aldehydes production. Production was optimized by extractive fermentation strategy using a surfactant to facilitate alka(e)nes excretion out of the cells in $C$. necator. We report here the highest level of alka(e) nes production by an engineered $C$. necator to date. We also demonstrated the first alka(e)nes production by $C$. necator mutant strain from $\mathrm{CO}_{2}$ as the sole carbon source.

\section{Material and methods}

\subsection{Strain}

For alkane production the parent strain of $C$. necator used was deleted for the PHA biosynthesis: Re2061 (H16 $\Delta$ phaCAB) (Lu et al., 2012). From the wild type strain C. necator H16 (ATCC17699, Gen ${ }^{\mathrm{r}}$ ) genes encoding for PHA synthase (phaC1, H16_A1437), $\beta$ ketothiolase A (phaA, H16_A1438), acetoacetyl-CoA reductases (phaB1, H16_A1439) were deleted. The strain was stored at $-80^{\circ} \mathrm{C}$ in liquid TBS medium (dextrose-free tryptic soy broth, Becton Dickinson, France) with 20\% glycerol (v/v).

\subsection{Plasmid and strain constructions}

The genes (Synpcc7942_1593 and Synpcc7942_1594) from Synechococcus elongatus were codon-optimized for C. necator $\mathrm{H} 16$ and synthesized by GenScript (Piscataway, NJ, USA) and received in pUC57-Kan. DNA sequence amplification was achieved using Phusion High-Fidelity PCR Master Mix with GC Buffer (New England Biolabs, Evry, France). Primers were obtained from Eurogentec, (Angers, France). Ado gene was amplified using the forward primer (5'- GTACCCGGGGATCCTCTAGAAAAGGAGGACAACCATGCCG-3') and the reverse primer (5'- GAACATGGTTGTCCTCCTTTTCAGACCGCGGCCAG-3'). Aar gene was amplified using the forward primer $\left(5^{\prime}-\right.$ CTGGCCGCGGTCTGAAAAGGAGGACAACCATGTTC -3') and the reverse primer (5'- CAAAACAGCCAAGCTTTCAGATGGCCAGCGC -3'). Synthetic ribosome binding site (RBS) and a nucleotide linker sequence were incorporated before each gene thank to forward primer. The RBS and linker sequences used (5'- AAAGGAGGACAACC - 3 ') were tested and described by Grousseau et al. (2014) and Lu et al. (2012). Empty plasmid pBBAD, used as backbone DNA, was digested by $\mathrm{XbaI}$ and HindIII. Restriction enzymes used were from New England Biolabs. PCR products and plasmid digest were gel purified before Gibson assembly. QIAQuickGel Extraction Kit (QIAGEN, Courtaboeuf, France) was used for gel purification of all DNA products. Plasmid extractions were carried out using QIAprep Spin Miniprep Kit (QIAGEN). Plasmid assembly was achieved by one-step isothermal DNA assembly protocol (Gibson et al., 2009). Plasmid 
sequencing was performed by GATC (Konstanz, Germany). Plasmids were transferred into Re2061 strain by electroporation. For electroporation of Re2061, a single colony was inoculated into $25 \mathrm{ml}$ of liquid TSB medium and grown up to $\mathrm{OD}_{600} \mathrm{~nm}$ at 0.5 . Culture was pelleted and washed twice in $25 \mathrm{ml}$ of fresh water at $4{ }^{\circ} \mathrm{C}$. Pellet cells were resuspended in $500 \mu \mathrm{l}$ of fresh water at $4{ }^{\circ} \mathrm{C}$. $150 \mu \mathrm{l}$ of cell suspension and $2 \mu \mathrm{l}$ of purified plasmid were transferred in a $0.2 \mathrm{~cm}$ cuvette (10573463, Fisher scientific, Illkirch). The electroporation was executed with the following parameters: $2.5 \mathrm{kV}, 25 \mu \mathrm{F}$, and $200 \Omega$. Immediately following electroporation, $900 \mu \mathrm{l}$ of SOC medium (Super Optimal Broth: $20 \mathrm{~g} / \mathrm{l}$ tryptone, $5 \mathrm{~g} / \mathrm{l}$ yeast extract, $0.58 \mathrm{~g} / \mathrm{l}$ $\mathrm{NaCl} ; 0.19 \mathrm{~g} / \mathrm{l} \mathrm{KCl}, 2 \mathrm{~g} / \mathrm{l} \mathrm{MgCl} 2,1.2 \mathrm{~g} / \mathrm{l} \mathrm{MgSO}_{4} 7 \mathrm{H}_{2} \mathrm{O}$ and $3.6 \mathrm{~g} / \mathrm{l}$ fructose) was added. The cells were transferred into a $1.5 \mathrm{ml}$ tube and incubated for $3 \mathrm{~h}$ at $30^{\circ} \mathrm{C}$ with shaking at $120 \mathrm{rpm}$. The electroporated strains were then plated on TBS medium Petri dish (TSB with addition of agar $20 \mathrm{~g} / \mathrm{l}, 10 \mathrm{mg} / \mathrm{l}$ gentamycin and $200 \mathrm{mg} / \mathrm{l}$ kanamycin).

\subsection{Media}

Rich medium consisted in $2.75 \%$ (w/v) dextrose-free tryptic soy broth (TSB, Becton Dickinson, France).

Minimal buffered medium used for flask culture (nitrogen starvation) was previously described by Lu et al. (2012) and contained the following salts: $4.0 \mathrm{~g} / \mathrm{l} \mathrm{NaH}_{2} \mathrm{PO}_{4}{ }_{2} \mathrm{H}_{2} \mathrm{O}, 4.6 \mathrm{~g} / \mathrm{l} \mathrm{Na}{ }_{2} \mathrm{HPO}_{4}$ $12 \mathrm{H}_{2} \mathrm{O}, 0.45 \mathrm{~g} / \mathrm{l} \mathrm{K} \mathrm{SO}_{4}, 0.39 \mathrm{~g} / \mathrm{l} \mathrm{MgSO}{ }_{4} 7 \mathrm{H}_{2} \mathrm{O}, 0.062 \mathrm{~g} / \mathrm{l} \mathrm{CaCl} 2 \mathrm{H}_{2} \mathrm{O}$ and $1 \mathrm{ml} / \mathrm{l}$ of a trace metal solution. The trace metal solution was prepared as follows: $15 \mathrm{~g} / \mathrm{FeSO}_{4} \cdot 7 \mathrm{H}_{2} \mathrm{O}, 2.4 \mathrm{~g} / \mathrm{l} \mathrm{MnSO} \mathrm{Mn}_{4} \cdot \mathrm{H}_{2} \mathrm{O}, 2.4 \mathrm{~g} /$ $1 \mathrm{ZnSO}_{4} \cdot 7 \mathrm{H}_{2} \mathrm{O}$, and $0.48 \mathrm{~g} / \mathrm{CuSO}_{4} \cdot 5 \mathrm{H}_{2} \mathrm{O}$ in $0.1 \mathrm{M} \mathrm{HCl}$. Fructose $(20 \mathrm{~g} / \mathrm{l})$ was used as carbon source. $\mathrm{NH}_{4} \mathrm{Cl}(0.5 \mathrm{~g} / \mathrm{l})$ was used as nitrogen source to reach a biomass concentration of about $1 \mathrm{~g} / \mathrm{l}$.

Minimal medium not buffered used in fed-batch culture (nitrogen limitation) was previously described by Aragao et al. (1996) and consisted in $0.19 \mathrm{~g} / \mathrm{l}$ of nitrilotriacetic acid, $0.06 \mathrm{~g} / \mathrm{l}$ of ferrous ammonium citrate, $0.5 \mathrm{~g} / \mathrm{l}$ of $\mathrm{MgSO}_{4} .7 \mathrm{H}_{2} \mathrm{O}, 0.01 \mathrm{~g} / \mathrm{l}$ of $\mathrm{CaCl}_{2} .2 \mathrm{H}_{2} \mathrm{O}$, and $1 \mathrm{ml}$ of trace element solution. The trace element solution composition was $0.3 \mathrm{~g} / \mathrm{l}$ of $\mathrm{H}_{3} \mathrm{BO}_{3}, 0.2 \mathrm{~g} / \mathrm{l}$ of $\mathrm{CoCl}_{2} \cdot 6 \mathrm{H}_{2} \mathrm{O}, 0.1 \mathrm{~g} / \mathrm{l}$ of $\mathrm{ZnSO}_{4} .7 \mathrm{H}_{2} \mathrm{O}, 0.03 \mathrm{~g} / \mathrm{l}$ of $\mathrm{MnCl}_{2} .4 \mathrm{H}_{2} \mathrm{O}, 0.03 \mathrm{~g} / \mathrm{l}$ of $\mathrm{Na}_{2} \mathrm{MoO}_{4} .2 \mathrm{H}_{2} \mathrm{O}$, $0.02 \mathrm{~g} / \mathrm{l}$ of $\mathrm{NiCl}_{2} \cdot \mathrm{H}_{2} \mathrm{O}, 0.01 \mathrm{~g} / \mathrm{l}$ of $\mathrm{CuSO}_{4} \cdot 5 \mathrm{H}_{2} \mathrm{O} .\left(\mathrm{NH}_{4}\right)_{2} \mathrm{SO}_{4}(5.0 \mathrm{~g} / \mathrm{l})$ was used as nitrogen source to reach a biomass concentration of about $7.5 \mathrm{~g} / \mathrm{l}$. After autoclaving the above medium, $40 \mathrm{ml}$ of a sterile phosphate solution containing $224 \mathrm{~g} / \mathrm{l}$ of $\mathrm{Na}_{2} \mathrm{HPO}_{4} \cdot 12 \mathrm{H}_{2} \mathrm{O}$ and $37.5 \mathrm{~g} / \mathrm{I}$ of $\mathrm{KH}_{2} \mathrm{PO}_{4}$ was aseptically added to the fermenter. Likewise, carbon substrate was added as a sterile fructose solution of $600 \mathrm{~g} / \mathrm{I}$ to reach $45 \mathrm{~g} / \mathrm{l}$ just before inoculation.

\subsection{Shake flask cultivation}

One glycerol stock was streaked on a TSB medium Petri dish (TSB with addition of agar $20 \mathrm{~g} / \mathrm{l}, 10 \mathrm{mg} / \mathrm{l}$ gentamycin and $200 \mathrm{mg} / \mathrm{l}$ kanamycin). The plate was incubated for $48-72 \mathrm{~h}$ at $30^{\circ} \mathrm{C}$. One colony was used to inoculate the first preculture grown flask with $10 \mathrm{ml}$ of liquid TBS medium $(10 \mathrm{mg} / \mathrm{l}$ gentamycin and $200 \mathrm{mg} / \mathrm{l}$ kanamycin) for $24 \mathrm{~h}$ at $30^{\circ} \mathrm{C}$ with continuous shaken at $120 \mathrm{rpm}$. The second preculture was grown for $16-24 \mathrm{~h}$ with $10 \mathrm{ml}$ of minimum buffered medium (100 mg/l kanamycin) in $100 \mathrm{ml}$ flask $\left(30^{\circ} \mathrm{C}, 120 \mathrm{rpm}\right)$. The preculture was grown for $120 \mathrm{~h}$ with $100 \mathrm{ml}$ of minimum buffered medium ( $100 \mathrm{mg} / \mathrm{l}$ kanamycin) in 11 flask $\left(30^{\circ} \mathrm{C}, 120 \mathrm{rpm}\right)$. When culture reached $80 \%$ of maximal biomass $0.1 \%(\mathrm{w} / \mathrm{v})$ of arabinose was added into the culture for induction of gene under $P_{B A D}$ control and $10 \%(\mathrm{v} / \mathrm{v})$ decane were added when necessary.

\subsection{Heterotrophic fed-batch culture conditions and bioreactor system}

The Fed-Batch culture was performed in a 61 (total volume) bioreactor containing an initial medium volume of 41 . Bioreactor was equipped with $\mathrm{pH}$, dissolved oxygen (DO), temperature and anti-foam controllers. The on-line monitoring and control systems of the reactor were handled by the software BioPAT ${ }^{\circledR}$ MFCS/win. Both $\mathrm{CO}_{2}$ and $\mathrm{O}_{2}$ in inlet and outlet gazes were analyzed using 1313 fermentation monitor INNOVA Airtech Instrument. The DO level in the reactor was controlled above $20 \%$ of air saturation by varying stirring speed and/or inlet air flow rate. Temperature was maintained at $30^{\circ} \mathrm{C}$. The $\mathrm{pH}$ was maintained at 7.0 by addition of a $16.6 \%(\mathrm{v} / \mathrm{v}) \mathrm{NH}_{3}$ solution during growth phase and then by addition of $4 \mathrm{~N} \mathrm{KOH}$ solution or $50 \%(\mathrm{v} / \mathrm{v})$ orthophosphoric acid during the nitrogen limiting phase. Nitrogen limitation was controlled by exponential feeding of $16.6 \%(\mathrm{v} / \mathrm{v}) \mathrm{NH}_{3}$ and fructose maintained in excess at $20 \mathrm{~g} / \mathrm{l}$ thank to an exponential feeding of fructose solution at $600 \mathrm{~g} / \mathrm{I}$.

\subsection{Autotrophic fed-batch culture conditions and bioreactor system}

The fed-Batch culture was performed in a 1.41 (total volume) bioreactor containing an initial medium volume of $1 \mathrm{l}$. Growth phase was performed first on fructose and then was switched on gas mixture. During the fructose growing phase, fructose was fed by an exponential feeding of fructose solution at $200 \mathrm{~g} / \mathrm{I}$ in order to have a specific growth rate of $0.16 \mathrm{~h}^{-1}$ and the dissolved oxygen level in the reactor was controlled above $20 \%$ of air saturation by varying stirring speed and/or inlet air flow rate. During the production phase on $\mathrm{CO}_{2}$, nitrogen limitation was controlled by an exponential feeding of $16.6 \%(\mathrm{v} / \mathrm{v})$ ammonia solution in order to have a specific growth rate of $0.02 \mathrm{~h}^{-1}$. A blend of $\mathrm{H}_{2}, \mathrm{O}_{2} \mathrm{CO}_{2}$ and $\mathrm{N}_{2}$ (60:2:10:28, molar ratio, Air liquid, France) was introduced into the reactor at a flow rate of $0.2 \mathrm{l} / \mathrm{min}$. Dissolved oxygen level in the reactor was controlled below $4 \%$ of air saturation by varying stirring speed in order to restrict the inhibition by $\mathrm{O}_{2}$ concentration of $C$. necator's hydrogenases. Though $C$. necator $[\mathrm{Ni}-\mathrm{Fe}]$ hydrogenases are among the most $\mathrm{O}_{2}$ tolerant ones, various studies reported different levels of inhibiting oxygen concentrations between $4 \%$ and $20 \% \mathrm{O}_{2}$ suggesting strain dependency. Phenomenological models reported inhibition constant $\left(\mathrm{K}_{\mathrm{i}}^{\mathrm{O} 2}\right)$ in the range of $0.11-$ $0.14 \mathrm{mM}$ corresponding to around $10 \%$ of the $\mathrm{O}_{2}$ (Siegel and Ollis, 1984). It was reported inhibition of the membrane bound hydrogenase by $\mathrm{O}_{2}$ concentrations as low as $0.05 \mathrm{mM} \mathrm{O}_{2}$ (4\% of dissolved oxygen in the reactor) with a $\mathrm{K}_{\mathrm{i}}^{\mathrm{O} 2}=0.110 \mathrm{mM}$ at pH5.5 at $30^{\circ} \mathrm{C}$ (Cracknell et al., 2009). Bioreactor was equipped with $\mathrm{pH}$, dissolved oxygen, temperature and pressure controllers. The on-line monitoring and control systems of the reactor were handled by the software BioPAT ${ }^{\circledR}$ MFCS/win. Temperature was maintained at $30{ }^{\circ} \mathrm{C}$. The $\mathrm{pH}$ was maintained at 7.0 by addition of $4 \mathrm{~N} \mathrm{KOH}$ solution or $50 \%(\mathrm{v} / \mathrm{v})$ orthophosphoric acid. Both $\mathrm{CO}_{2}$ and $\mathrm{O}_{2}$ in inlet and outlet gas were analyzed using BlueInOne from BlueSens and $\mathrm{H}_{2}$ in inlet and outlet gas was analyzed using a MicroGC 490 Agilent with agilent J\&W CP-COX column and argon as vector gaz. $\mathrm{O}_{2}$ concentration was controlled below $4 \%$ to avoid the explosion risk. Overpressure inside the bioreactor was increased three times (from 0 to 50 mbars, then to 120 and finally to 300 mbars) during the fermentation in order to improve the gas transfer rates $\left(k_{L} \mathrm{a}\right)$.

\subsection{Analytical procedures}

Biomass concentration was quantitated by cell dry weight determination. Culture medium was harvested and filtrated on $0.22 \mu \mathrm{m}$ pore-size polyamide membranes (Sartorius AG, Göttingen, Germany), which were then dried to a constant weight at $60^{\circ} \mathrm{C}$ under partial vacuum $(200 \mathrm{mmHg}$, i.e. approximately $26.7 \mathrm{kPa}$ ). Total biomass growth was also followed by measuring the optical density at $600 \mathrm{~nm}$ (OD600nm) using a visible spectrophotometer (Hach Lange) with a $2 \mathrm{~mm}$ absorption cell (HELLMA). 
Culture supernatants were obtained by centrifugation at $12,000 \mathrm{~g}$ during $4 \mathrm{~min}$ and filtration $(0.2 \mu \mathrm{m}$ Minisart RC4, Sartorius) of the culture samples and used for substrate and organic acid determination. The residual substrate and organic acid concentrations were quantified by high-performance liquid chromatography (HPLC). The HPLC instrument (e2695, Waters) was equipped with an ion-exchange column (Aminex HPX-87H, $300 \times 7.8 \mathrm{~mm}$, Bio-Rad) protected with a guard column (Cation $\mathrm{H}+$ cartridge, $30 \times 4.6 \mathrm{~mm}$, Bio-Rad) and coupled to a RI detector and an UV detector $(\lambda=210 \mathrm{~nm})$. The column was eluted with $2.5 \mathrm{mM} \mathrm{H}_{2} \mathrm{SO}_{4}$ as a mobile phase at $50{ }^{\circ} \mathrm{C}$ at a flow rate of $0.5 \mathrm{ml} /$ $\min$.

\subsection{Alkane, alkene and aldehyde quantification by GC-MS/MS}

Hydrocarbons were extracted by liquid/liquid extraction with hexane in supernatant (extracellular) and pelleted cells (intracellular). Culture sample was centrifuged at $12,000 \mathrm{~g}$ during $4 \mathrm{~min} 1 \mathrm{ml}$ of supernatant was mixed with $1 \mathrm{ml}$ of hexane, vortexed for $10 \mathrm{~min}$ and centrifuged at $2000 \mathrm{rpm}$ for $2 \mathrm{~min} 50 \mu \mathrm{l}$ of the upper phase was added to $50 \mu \mathrm{l}$ of $20 \mathrm{mg} / \mathrm{l}$ tetradecane in hexane (used as internal standard) into fresh vial and analyzed by GC-MS/MS. Cell pellets (corresponding to $1 \mathrm{ml}$ of culture) were resuspended in $1 \mathrm{ml}$ of water and liquid/liquid extraction in hexane was performed as described for supernatant before GC-MSMS analysis. The decane phase was sampled after centrifugation at $12,000 \mathrm{~g}$ during $4 \mathrm{~min} 50 \mu \mathrm{l}$ of decane phase was added to $50 \mu \mathrm{l}$ of $20 \mathrm{mg} / \mathrm{l}$ tetradecane in hexane (used as internal standard) into fresh vial and analyzed by GC-MS/MS.

The samples were analyzed on a column Rtx $^{\circledR}-5$ Sil MS (30 m $0.25 \mathrm{~mm}$ ID $0.25 \mu \mathrm{m}$ df, Restek) with GC instrument (HP7890A, Agilent) coupled to a mass spectrometer (Quattro micro ${ }^{\mathrm{TM}} \mathrm{GC}$, Waters). For GC separation we used the following method: after $1 \mu \mathrm{l}$ splitless injection (inlet temperature at $250^{\circ} \mathrm{C}$ ) into the column, the oven was held at $50{ }^{\circ} \mathrm{C}$ for $1 \mathrm{~min}$ The temperature was ramped up to $180^{\circ} \mathrm{C}$ at $13^{\circ} \mathrm{C} / \mathrm{min}$, up to $185^{\circ} \mathrm{C}$ at $5^{\circ} \mathrm{C} / \mathrm{min}$, up to $190{ }^{\circ} \mathrm{C}$ at $0.5^{\circ} \mathrm{C} / \mathrm{min}$, up to $305^{\circ} \mathrm{C}$ at $15^{\circ} \mathrm{C} / \mathrm{min}$ and then held at $305^{\circ} \mathrm{C}$ for an additional $2 \mathrm{~min}$ The flow rate of the carrier gas helium was $1.0 \mathrm{ml} / \mathrm{min}$.

The mass spectrometer source was operated both in CI-Full scan mode (from $50 \mathrm{~m} / \mathrm{z}$ to $500 \mathrm{~m} / \mathrm{z}$ ) and in CI-MRM mode. In CIMRM mode, transition pattern (parent/daughter for a specific collision force at defined retention time) was determined for each compound by using standard compounds. Quantification was performed using transition area normalized by internal standard thank to calibration curve by QuanLynx software from Waters.

\section{Results}

\subsection{Engineering the C. necator strain Re2061-pLC10}

C. necator has the ability to strongly redirect its carbon flow towards acetyl-coA, precursor for the PHA, under nutrient limitation or depletion conditions. Acetyl-CoA is also the metabolic precursor for alkane biosynthesis in cyanobacteria. In order to take advantage of this natural ability of $C$. necator, a synthetic metabolic pathway was designed and expressed in a C. necator Re2061 mutant deficient in PHA synthesis (Fig. 1). The Re2061 strain was deleted for the phaCAB operon (phaC1, H16_A1437 ; phaA, H16_A1438 ; phaB1, H16_A1439) encoding for PHA synthase, $\beta$ ketothiolase A and acetoacetyl-CoA reductases (Lu et al., 2012). The synthetic alkane pathway contained two Synechococcus elongatus genes encoding an acyl-ACP reductase (AAR) and an aldehyde deformylating oxygenase (ADO) (PCC7942-orf1594 and PCC7942-orf1593 respectively) (Schirmer et al., 2010) and was expressed into pBBAD plasmid (Fukui et al., 2011). pBBAD contained arabinose-inducible promoter $P_{B A D}$ allowing to induce gene expression. That promoter was shown to improve production of isopropanol in $C$. necator by uncoupling growth and production

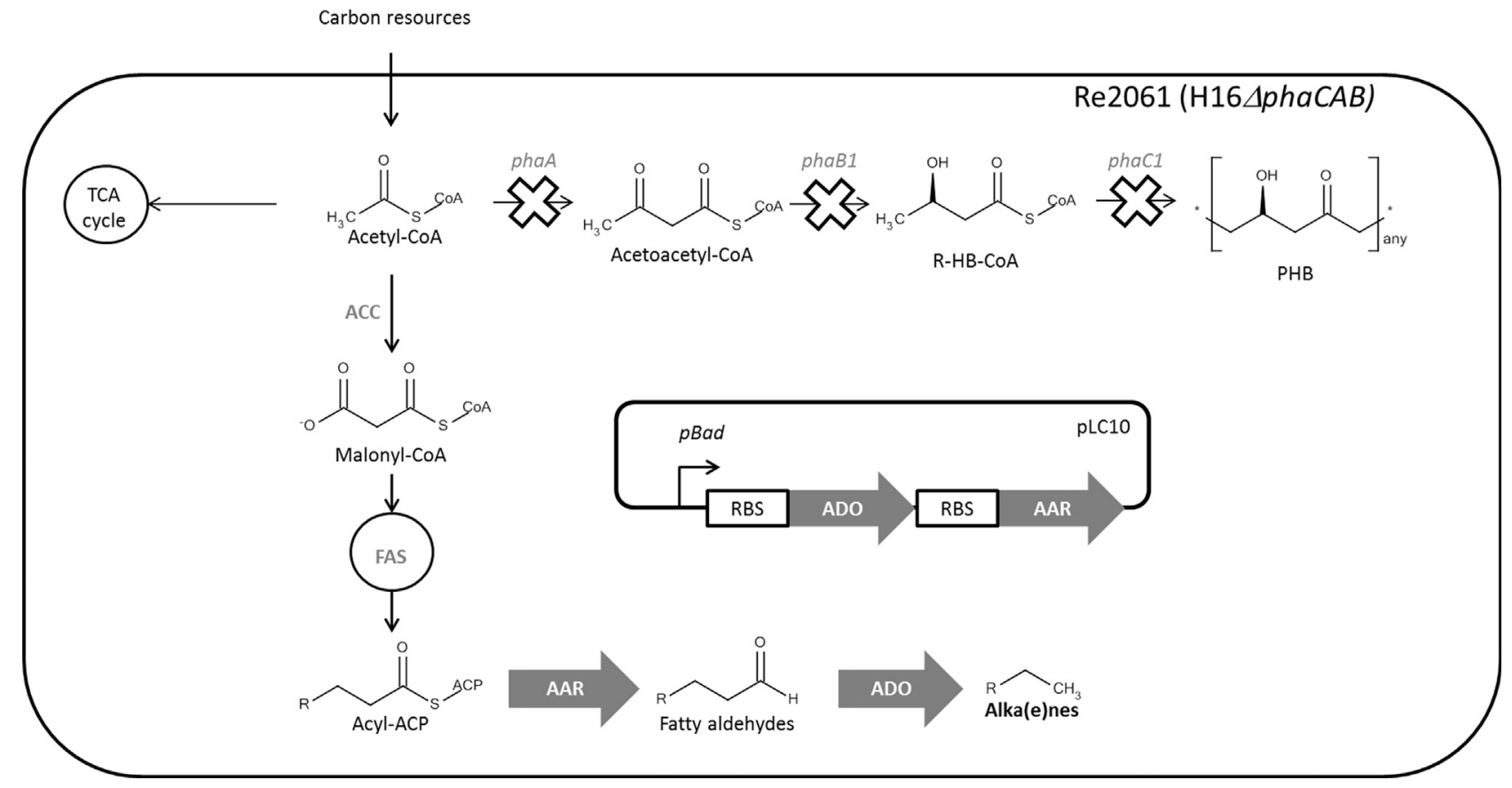

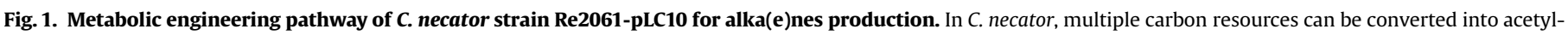

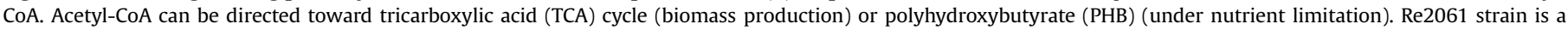

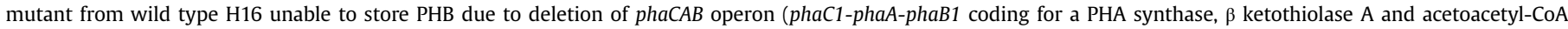

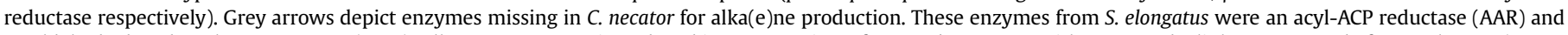

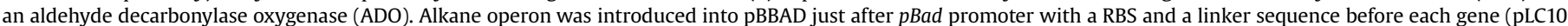
plasmid). 
and therefore reducing product inhibition (Grousseau et al., 2014). Because of differences in genome GC content between S. elongatus PCC 7942 (about 56\% GC) and C. necator (about 67\% GC) aar and ado genes were codon optimized for $C$. necator in order to improve heterologous enzyme expression. For pulling further the carbon flow towards the final product, the ado gene was placed the closest to the promoter in order to have higher expression as demonstrated by Grousseau et al. (2014). As C. necator possess genes coding for potential ferredoxin (two ferredoxins 2Fe-2S, H168A1164 and H16_B0545) and ferredoxin reductase (two ferredoxin-NADP reductases, H16_B0102 and H16_B0739 with EC:1.18.1.2) (Stothard et al., 2005), we expected that ferredoxin and ferredoxin reductase components essential for ADO activity could be provided by endogenous $C$. necator proteins as it has been shown in E. coli (Schirmer et al., 2010). Finally between each gene, a synthetic ribosome-binding site (RBS) and a nucleotide linker sequence were incorporated. The RBS and linker sequences used were optimized, tested and described by Grousseau et al. (2014) and Lu et al. (2012).

\subsection{Heterotrophic production of alka(e)nes by Re2061-pLC10 C.} necator strain

\subsubsection{Flask culture under nitrogen starvation}

Nutrient starvation is often used as a trigger for PHA production. Therefore Re2061-pLC10 strain was cultivated in $100 \mathrm{ml}$ of mineral medium containing nitrogen at a concentration to reach a biomass of about $1 \mathrm{~g} / \mathrm{l}$ and fructose as sole carbon source. Just before total nitrogen depletion (biomass concentration around $0.8 \mathrm{~g} / \mathrm{l}$ of cell dry weight), expression of alkane operon was induced by addition of $0.1 \%$ of arabinose. The strain Re2061 transformed with the empty plasmid pBBAD was used as a reference strain under the same cultivation conditions. After nitrogen depletion, in the reference strain carbon from fructose was directed toward pyruvate (up to $1.45 \pm 0.14 \mathrm{~g} / \mathrm{l})$. Re2061-pLC10 strain containing the alkane operon still secreted pyruvate (up to $1.48 \pm 0.18 \mathrm{~g} / \mathrm{l}$ ) and produced pentadecane up to $107 \pm 3 \mu \mathrm{g} / \mathrm{l}$ into the supernatant and $80 \pm 3 \mu \mathrm{g} / \mathrm{l}$ into the cell pellets. In order to further pull the alkane flow out of the cells, decane $(10 \%, \mathrm{v} / \mathrm{v})$ was added into the broth in another set of cultivation flasks. Pentadecane was only detected into the decane phase and the final concentration reached $1.27 \pm 0.4 \mathrm{mg} / \mathrm{l}$. In this condition, addition of decane improved four times the pentadecane production of Re2061-pLC10 strain from $0.22 \pm 0.01 \mathrm{mg} / \mathrm{g}_{\mathrm{CDW}}$ to $0.94 \pm 0.33 \mathrm{mg} / \mathrm{g}_{\mathrm{CDW}}$ (Fig. 2).

\subsubsection{Fed-batch under nitrogen limitation}

Sustaining a controlled residual growth improved the PHB specific production rate without altering production yield (Grousseau et al., 2013) suggesting that cultivated Re2061-pLC10 strain under nitrogen limitation could enhance alkane production as well. Two steps fermentation was performed in bioreactor uncoupling biomass and alkane production. During the first step all nutrients were provided in excess allowing maximal growth rate in order to reach $10 \mathrm{~g}_{\mathrm{CDW}} / \mathrm{l}$ of biomass. Then, after total depletion of nitrogen, the reactor was fed with an ammonia solution to support a residual growth rate of $0.02 \mathrm{~h}^{-1}$. Alkane operon expression was induced by adding $0.1 \%(\mathrm{w} / \mathrm{w})$ of arabinose. Two conditions were tested: without and with addition of $10 \%$ decane at induction time. Carbon and elemental balances were closed at $93 \%$ and $77 \%$, respectively.

After nitrogen depletion, Re2061-pBBAD strain, used as a reference, quickly produced pyruvate (up to $1 \pm 0.05 \mathrm{~g} / \mathrm{l}$ ) and immediately re-consumed it. In this condition, carbon excess from fructose was directed toward acetate $(0.9 \pm 0.05 \mathrm{~g} / \mathrm{l})$, citrate $(0.4 \pm 0.02 \mathrm{~g} / \mathrm{l})$ and succinate $(0.9 \pm 0.04 \mathrm{~g} / \mathrm{l})$ (Table 1$)$. In presence of $10 \%$ decane the same observations were done meaning that

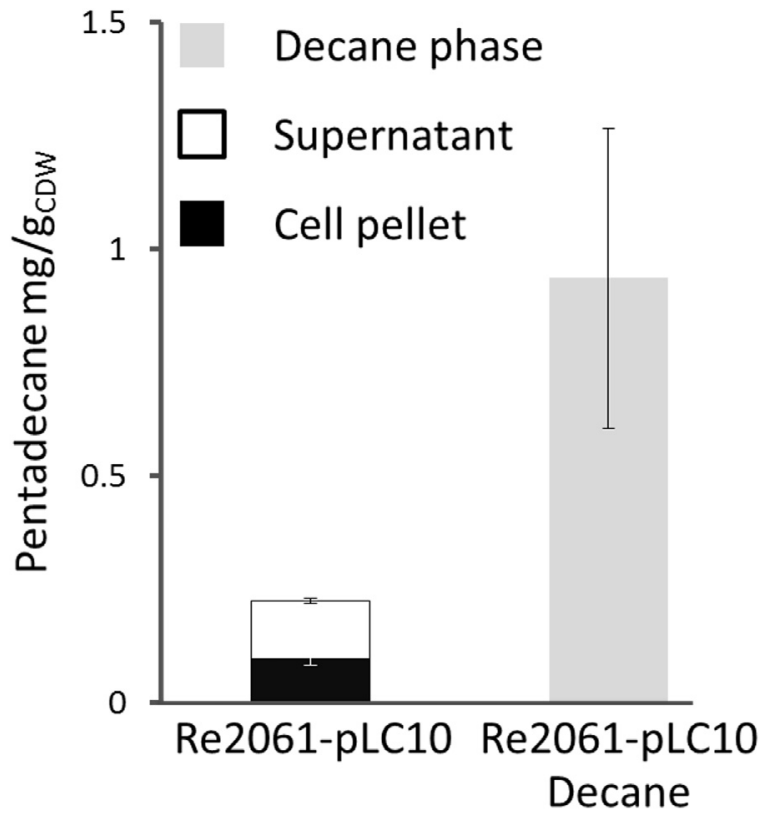

Fig. 2. Pentadecane production by $C$. necator strain Re2061-pLC10 in flask under nitrogen starvation without and with addition of $10 \%(\mathrm{v} / \mathrm{v})$ decane after $96 \mathrm{~h}$ of induction with $0.1 \%(\mathrm{w} / \mathrm{v})$ of arabinose. Results indicated in $\mathrm{mg}$ of pentadecane per $\mathrm{g}$ of cell dry weight, are the mean of independent triplicates. Dark lines indicate standard error $(n=3)$.

presence of $10 \%$ decane did not affect the carbon distribution. During growth phase Re2061-pLC10 strain grew at a maximal rate up to $0.21 \pm 0.01 \mathrm{~h}^{-1}$ and $0.23 \pm 0.01 \mathrm{~h}^{-1}$, without and with $10 \%$ decane, respectively. After more than $80 \mathrm{~h}$ of nitrogen limitation, the final biomass concentrations were $36.0 \pm 1.2 \mathrm{~g} / \mathrm{l}$ and $35.8 \pm 1.0 \mathrm{~g} / \mathrm{l}$ (without and with $10 \%$ decane, respectively) (Table 1). As observed in the reference strain, Re2061-pLC10 strain produced transiently pyruvate and then acetate $(2.0 \pm 0.1 \mathrm{~g} / \mathrm{l})$, citrate $(0.3 \pm 0.02 \mathrm{~g} / \mathrm{l})$ and succinate $(0.4 \pm 0.02 \mathrm{~g} / \mathrm{l})$ (Table 1$)$. In presence of $10 \%$ decane the production of acetate was lower $(1.5 \pm 0.05 \mathrm{~g} / \mathrm{l})$ and slightly higher for citrate and succinate (both at $1.0 \pm 0.05 \mathrm{~g} / \mathrm{l})$.

Nitrogen limited fed-batch culture of Re2061-pLC10 strain resulted in a production of $337 \mathrm{mg} / \mathrm{l}$ of total hydrocarbons, consisting in $241 \pm 12.1 \mathrm{mg} / \mathrm{l}$ of pentadecane, $88 \pm 4.1 \mathrm{mg} / \mathrm{l}$ of heptadecene, $8 \pm 0.4 \mathrm{mg} / \mathrm{l}$ of heptadecane, $0.4 \pm 0.02 \mathrm{mg} / \mathrm{l}$ of tridecane, together with small amounts of hexadecanal $8 \pm 0.4 \mathrm{mg} / \mathrm{l}$ (Table 1 ). Hydrocarbons produced were mostly secreted into the supernatant (more than $80 \%$ ). Alka(e)nes (pentadecane, heptadecene and tridecane) were detected rapidly after induction while aldehyde (hexadecanal) was detected only after $60 \mathrm{~h}$ of culture (Fig. 3a). Addition of $10 \%$ of decane during N-limited fed-batch culture of Re2061-pLC10 strain led to a higher production of $670 \pm 22.3 \mathrm{mg} / \mathrm{l}$ of total hydrocarbons, containing $435 \pm 18.9 \mathrm{mg} / \mathrm{l}$ of alkanes consisting in $286 \pm 13.6 \mathrm{mg} / \mathrm{l}$ of pentadecane, $130 \pm 6.5 \mathrm{mg} / \mathrm{l}$ of heptadecene, and $18 \pm 0.9 \mathrm{mg} / \mathrm{l}$ of heptadecane. In addition to alka(e) nes Re2061-pLC10 strain produced $235 \pm 11.9 \mathrm{mg} / \mathrm{l}$ of hexadecanal, the corresponding aldehyde precursor of pentadecane (Table 1). All products were detected from the induction time in the decane phase and none was detected into the supernatant or cellular pellet (Fig. 3b). Because of residual presence of tridecane in the decane solution used it was not possible to reliably quantify a tridecane biosynthesis. In this condition, total production of Re2061-pLC10 strain was $9.6 \mathrm{mg} / \mathrm{g}_{\mathrm{CDW}}$ in absence of decane and $18.7 \mathrm{mg} / \mathrm{g}_{\mathrm{CDW}}$ in presence of decane organic phase. 
Table 1

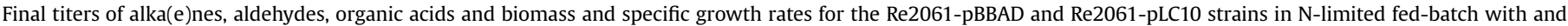
without an organic phase (decane) on various $\mathrm{C}$-sources (Fructose or $\mathrm{CO}_{2}$ ) in the production phase.

\begin{tabular}{|c|c|c|c|c|c|c|c|c|c|c|}
\hline \multirow[b]{2}{*}{$\begin{array}{l}\text { Decane } \\
\text { Carbon sources }^{\text {a }}\end{array}$} & & \multicolumn{4}{|c|}{ Re2061-pBBAD } & \multicolumn{5}{|c|}{ Re2061-pLC10 } \\
\hline & & $\begin{array}{l}\text { NO } \\
\text { Fru/Fru }\end{array}$ & & $\begin{array}{l}\text { YES } \\
\text { Fru/Fru }\end{array}$ & & $\begin{array}{l}\text { NO } \\
\text { Fru/Fru }\end{array}$ & & $\begin{array}{l}\text { YES } \\
\text { Fru/Fru }\end{array}$ & & $\begin{array}{l}\mathrm{NO} \\
\text { Fru/CO }\end{array}$ \\
\hline Tridecane (C13) & $\mathbf{m g} / \mathbf{l}$ & & & & & 0.43 & \pm 0.02 & 0 & & 0 \\
\hline Pentadecane (C15) & $\mathrm{mg} / \mathbf{l}$ & & & & & 241.2 & \pm 12.1 & 286.2 & \pm 13.6 & 0.75 \\
\hline Heptadecane (C17) & $\mathrm{mg} / \mathbf{l}$ & & & & & 7.66 & \pm 0.4 & 18.0 & \pm 0.9 & 0.85 \\
\hline Heptadecene (C17:1) & $\mathbf{m g} / \mathbf{l}$ & & & & & 87.7 & \pm 4.1 & 130.6 & \pm 6.5 & 2.8 \\
\hline Hexadecanal (C16) & $\mathrm{mg} / \mathbf{l}$ & & & & & 7.8 & \pm 0.4 & 235.6 & \pm 11.9 & 0 \\
\hline Total alka(e)nes & $\mathrm{mg} / \mathbf{l}$ & & & & & 337.0 & \pm 15.2 & 434.8 & \pm 18.9 & 4.4 \\
\hline Total products & mg/l & & & & & 344.8 & \pm 17.1 & 670.4 & \pm 22.3 & 4.4 \\
\hline Acetic acid & $\mathrm{g} / 1$ & 0.9 & \pm 0.05 & 0.9 & \pm 0.05 & 2.0 & \pm 0.1 & 1.5 & \pm 0.05 & 0.1 \\
\hline Citric acid & $\mathrm{g} / \mathbf{l}$ & 0.4 & \pm 0.02 & 0.3 & \pm 0.02 & 0.3 & \pm 0.02 & 1.0 & \pm 0.02 & 2.0 \\
\hline Succinic acid & $\mathrm{g} / \mathbf{1}$ & 0.9 & \pm 0.04 & 0.4 & \pm 0.04 & 0.4 & \pm 0.02 & 1.0 & \pm 0.04 & 0 \\
\hline Total organic acids & $\mathrm{g} / \mathbf{l}$ & 2.2 & \pm 0.11 & 1.7 & \pm 0.09 & 2.7 & \pm 0.13 & 3.5 & \pm 0.1 & 2.1 \\
\hline Biomass CDW & $\mathrm{g} / \mathbf{1}$ & 22.2 & \pm 1.0 & 20.4 & \pm 1.0 & 36.0 & \pm 1.2 & 35.8 & \pm 1.0 & 5.8 \\
\hline$\mu \max$ & $\mathbf{h}^{-\mathbf{1}}$ & 0.15 & \pm 0.01 & 0.15 & \pm 0.01 & 0.21 & \pm 0.01 & 0.23 & \pm 0.01 & n.a. \\
\hline
\end{tabular}

n.a. not applicable: growth was controlled at $0.16 \mathrm{~h}^{-1}$ and $0.03 \mathrm{~h}^{-1}$ during phases on fructose and $\mathrm{CO}_{2}$, respectively (see Section 3.3 )

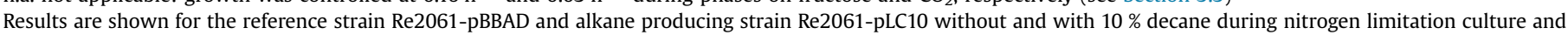
for strain Re2061-pLC10 on $\mathrm{CO}_{2}$. Results are the mean of independent triplicates.

${ }^{a}$ Carbon sources used during growth phase/production phase.

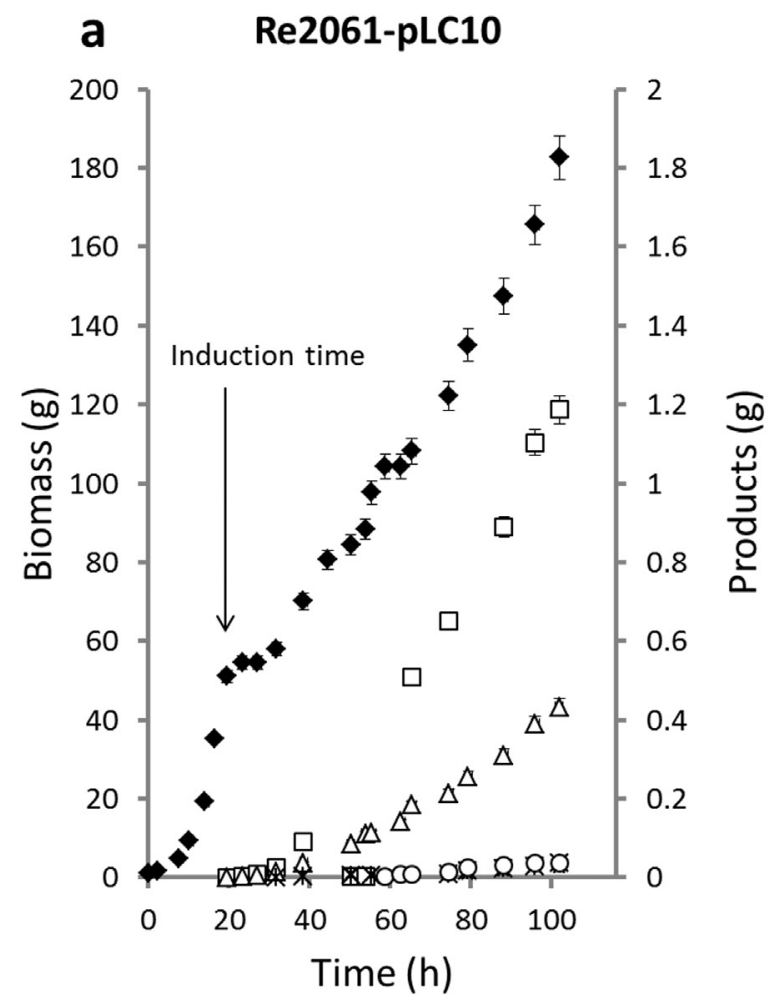

Time (h) b Re2061-pLC10-Decane

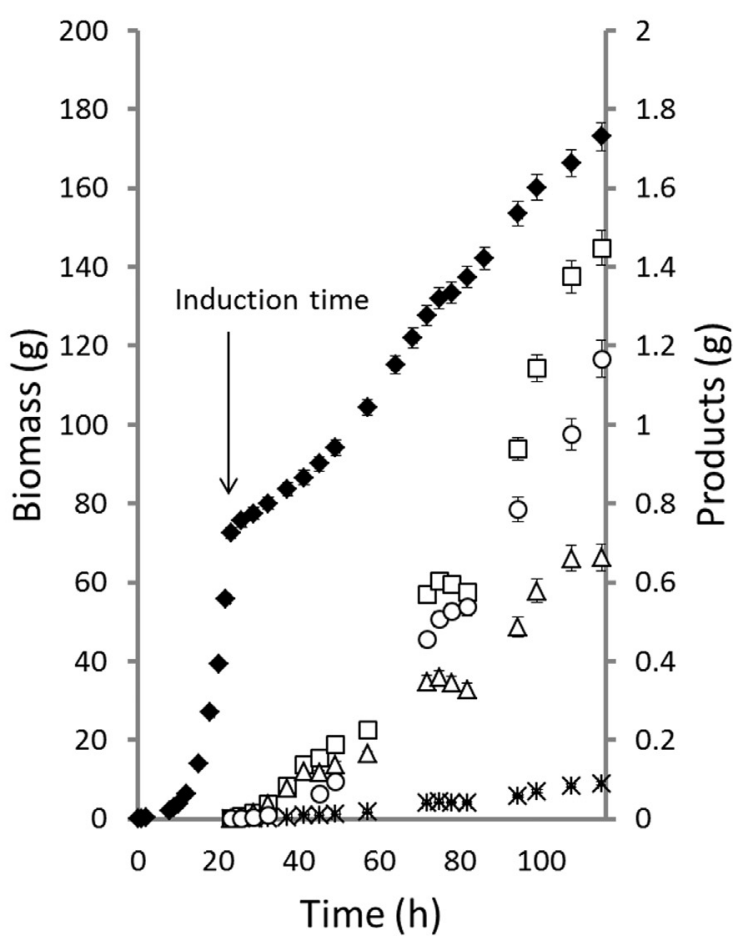

\section{- Biomass \\ X Tridecane \\ Pentadecane \\ * Heptadecane $\triangle$ Heptadecene \\ O Hexadecanal}

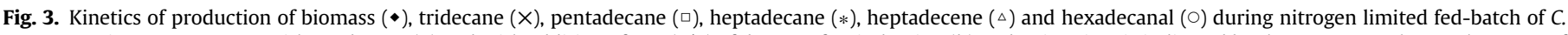

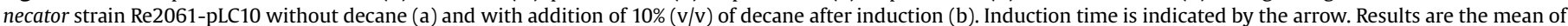
independent triplicates. Dark bars indicate standard deviation $(n=3)$. 

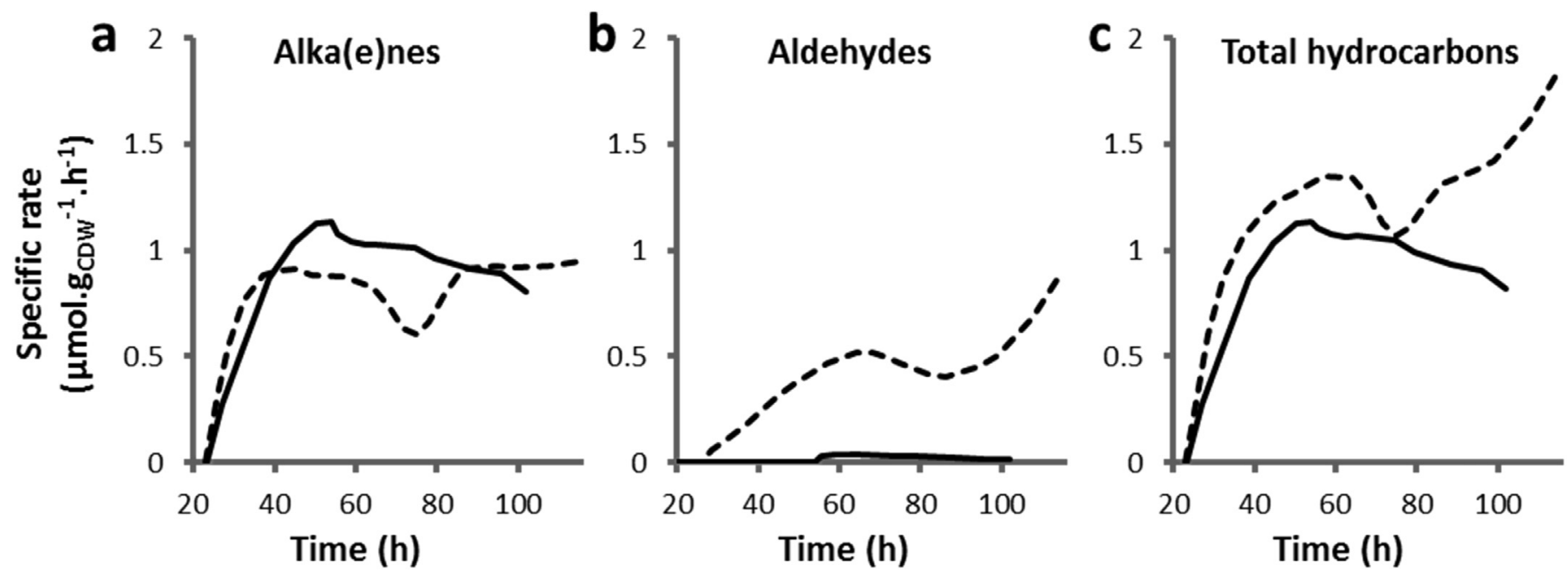

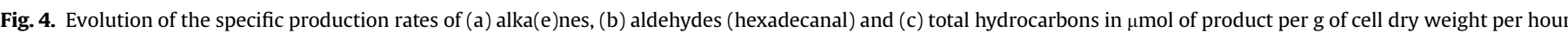
for both fermentation of Re2061-pLC10 without decane (full line) and with decane (dotted line).

\subsubsection{Kinetics of specific hydrocarbon production rates}

In order to analyze at the cell level, the specific production rates were calculated for each product (pentadecane, heptadecene, heptadecane and hexadecanal). The data showed that the specific production rate of total hydrocarbons was strongly enhanced by the presence of a decane organic phase in the bioreactor (Fig. 4c). A maximum rate of $1.85 \mu$ mole $\mathrm{g}_{\mathrm{CDW}}{ }^{-1} \mathrm{~h}^{-1}$ was calculated with Re2061-pLC10 strain compared to $1.14 \mu$ mole $_{\mathrm{CDW}}{ }^{-1} \mathrm{~h}^{-1}$ in absence of decane. This increase was mainly the result of a strong aldehyde production rate (up to $0.9 \mu$ mole $\mathrm{g}_{\mathrm{CDW}}{ }^{-1} \mathrm{~h}^{-1}$ ) (Fig. $4 \mathrm{~b}$ ) whereas the alka(e)ne production rates were slightly lower in presence of decane (Fig. 4a).

\subsubsection{Carbon distribution between organics acids, aldehydes and} alkanes

In order to follow the carbon fate, final carbon repartition into extracellular metabolites (in $\mathrm{Cmol}$ per Cmol of cell dry weight) between Re2061-pBBAD strain and Re2061-pLC10 strain was compared without and with decane organic phase (Fig. 5). We showed that in Re2061-pBBAD, addition of decane did not affect carbon distribution. In Re2061-pLC10 strain, carbon flux toward organic acids strongly decreased compared to Re2061-pBBAD strain (from $0.13 \mathrm{Cmol} / \mathrm{Cmol}_{\mathrm{CDW}}$ to $0.077 \mathrm{Cmol} / \mathrm{Cmol}_{\mathrm{CDW}}$ ) and we observed carbon flux toward alka(e)nes production up to $0.024 \mathrm{Cmol} / \mathrm{Cmol}_{\mathrm{CDW}}$. Decane addition in Re2061-pLC10 strain did not significantly decrease carbon flux toward organic acids compared to Re2061-pBBAD strain (from $0.13 \mathrm{Cmol} / \mathrm{Cmol}_{\mathrm{CDW}}$ to $\left.0.12 \mathrm{Cmol} / \mathrm{Cmol}_{\mathrm{CDW}}\right)$ but strongly increased carbon flux toward

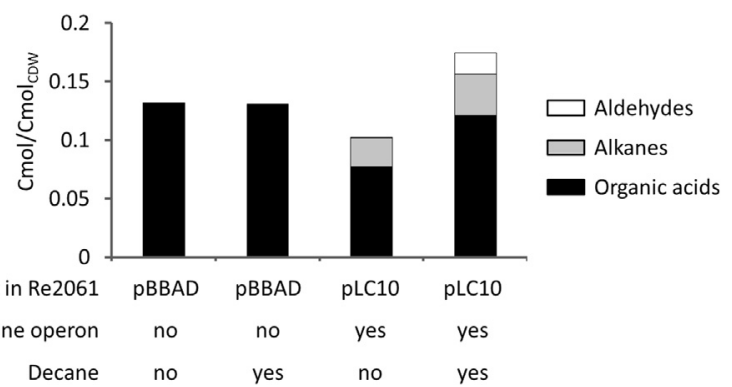

Fig. 5. Final carbon repartition (distribution) into extracellular metabolites (organic acids, alkanes and aldehydes) in $\mathrm{Cmol}$ per $\mathrm{Cmol}$ of cell dry weight for strains Re2061 bearing the empty plasmid pBBAD or the alkane operon pLC10 plasmid in presence or absence of decane. alka(e)nes and aldehydes production up to $0.035 \mathrm{Cmol} / \mathrm{Cmol}_{\mathrm{CDW}}$ and $0.018 \mathrm{Cmol} / \mathrm{Cmol}_{\mathrm{CDW}}$ respectively.

3.2.5. Relative composition of fatty acids in the biomass and of alka (e)nes/aldehydes produced

We analyzed fatty acid composition in the reference strain Re2061-pBBAD and in the alkane producing strain Re2061-pLC10 without and with $10 \%$ of decane during fed batch cultivation. No differences in fatty acid composition were observed neither between the 2 strains nor in presence or absence of decane organic phase (data not shown). At the end of the fed-batch culture, in absence and in presence of decane the Re2061-pLC10 strain fatty acid composition (as percentage of total FA) was $65 \%$ of palmitic acid, $20 \%$ of palmitoleic, acid $10 \%$ of oleic acid and less than $5 \%$ of myristic acid (Fig. 6). In absence of decane, the relative composition of total products of Re2061-pLC10 strain (as percentage of total hydrocarbons) mirrored the FA composition: around $75 \%$ of pentadecane, $20 \%$ of heptadecene and less than $5 \%$ of tridecane, heptadecane and hexadecanal together. Similar statement could be made in presence of decane taking into account that the $45 \%$ of pentadecane and $35 \%$ of hexadecanal derived both from the same substrate: palmitic acid accounting for $80 \%$ (Fig. 6).

\subsection{Autotrophic production of alka(e)nes by Re2061-pLC10 C. ne- cator strain}

Two steps fermentation was performed in bioreactor uncoupling biomass production on fructose and alka(e)nes production on $\mathrm{CO}_{2}$ as the sole carbon source. During the growing phase, fructose was fed to control the specific growth rate at $0.16 \mathrm{~h}^{-1}$ and

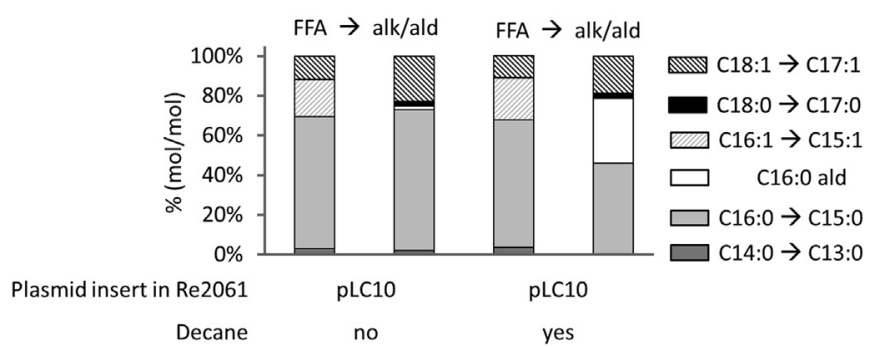

Fig. 6. Comparison of fatty acid composition in biomass (precursor) and alka(e)nes and aldehydes (products) profile in percentage in mol of each compound divided by mol of total at the end of fed-batch culture of the strain Re2061 bearing the alkane operon pLC10 plasmid in presence or absence of decane. 
nitrogen was provided to reach $3 \mathrm{~g} / \mathrm{l}$ of cell dry weight. When nitrogen was totally consumed (around $3 \mathrm{~g} / \mathrm{l}$ of CDW) fructose feeding was stopped, and nitrogen was fed to support a residual specific growth rate at $0.02 \mathrm{~h}^{-1} \cdot \mathrm{CO}_{2}$ feeding was performed by bubbling of a gas mixture containing $\mathrm{H}_{2}, \mathrm{O}_{2}$ and $\mathrm{CO}_{2}$ (60:2:10). Cultivation was performed under $\mathrm{O}_{2}$-limited condition in order to both avoid the explosion risk and restrict the inhibition of $C$. necator hydrogenases by $\mathrm{O}_{2}$ concentration. Alka(e)nes production was induced by addition of $0.1 \%$ of arabinose. Arabinose was measured through the whole fermentation and was not consumed by the bacteria. When nitrogen was depleted, Re2061-pLC10 transitorily produced pyruvate up to $1.3 \mathrm{~g} / \mathrm{l}$. After $56 \mathrm{~h}$ of nitrogen limitation and production phase on $\mathrm{CO}_{2}$, the final level of biomass was $5.8 \mathrm{~g} / \mathrm{l}$ and acetate and citrate were also produced up to $0.11 \mathrm{~g} /$ 1 and $2.0 \mathrm{~g} / \mathrm{l}$ respectively. Production phase on $\mathrm{CO}_{2}$ of Re2061pLC10 resulted in production of $4.4 \mathrm{mg} / \mathrm{l}$ of total alka(e)nes consisting in $0.75 \mathrm{mg} / \mathrm{l}$ of pentadecane, $0.85 \mathrm{mg} / \mathrm{l}$ of heptadecane and $2.8 \mathrm{mg} / \mathrm{l}$ of heptadecene (Table 1). In this condition, alka(e)nes produced were found both in supernatant and in cell pellets (Fig. 7). Three step overpressure upshifts led to an increase in the alkane production rates likely resulting from the increase in the gas transfer rates (Fig. 8).

\section{Discussion}

C. necator is a versatile organism industrially used for more than a decade for PHB synthesis (Chen, 2009; Reinecke and Steinbüchel, 2009) and recently engineered for biofuel production (Bi et al., 2013; Chen et al., 2015; Grousseau et al., 2014; H. Li et al., 2012; Lu et al., 2012; Müller et al., 2013; Torella et al., 2015). In this study we engineered a $C$. necator strain Re2061-pLC10 able to produce alka(e)nes. Our strategy was based on redirecting the carbon flow from PHB synthesis toward alkane production. For that purpose a heterologous alkane pathway from $S$. elongatus was expressed in C. necator mutant strain unable to produce PHB. Push and pull strategy led to high alka(e)ne production in $C$. necator from fructose.

In order to keep natural abilities of $C$. necator and efficiently redirect the carbon towards alkane pathway, a push and pull

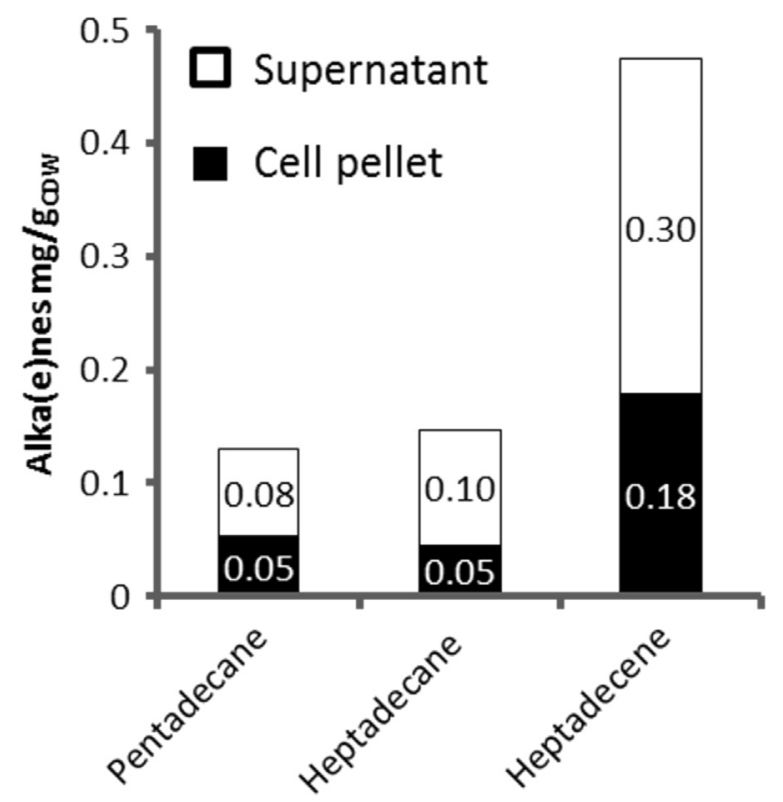

Fig. 7. Final production level of pentadecane, heptadecane, heptadecene into cell pellets (dark) and supernatant (white) at the end of fed-batch of $C$. necator strain Re2061-pLC10 under autotrophic condition expressed in $\mathrm{mg} / \mathrm{g}_{\mathrm{CDW}}$.

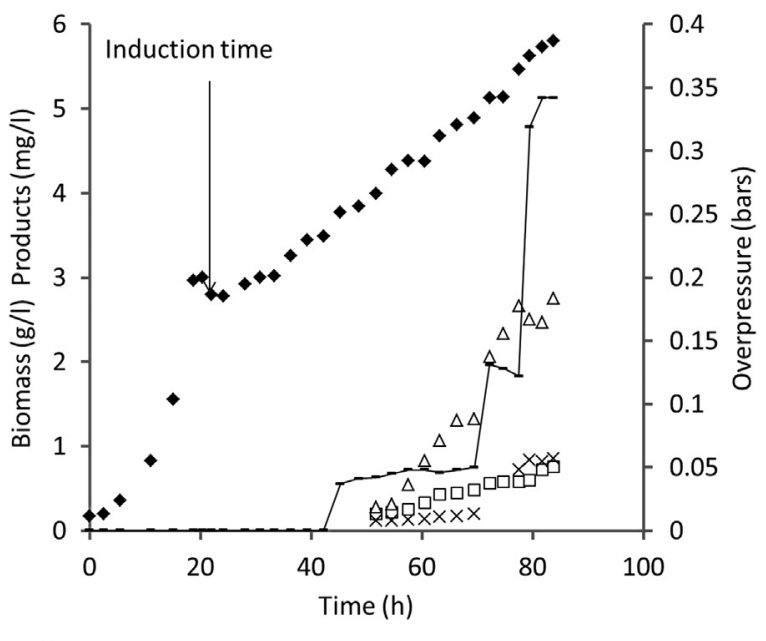

- Biomass $\square$ Pentadecane $*$ Heptadecane $\triangle$ Heptadecene

$$
\rightarrow \text { - Overpressure }
$$

Fig. 8. Kinetics of production of biomass $(\bullet)$, pentadecane $(\square)$, heptadecane $(*)$, heptadecene $(\Delta)$ and overpressure (—-) during fed-batch of $C$. necator strain Re2061-pLC10 under autotrophic condition. Induction time is indicated by arrow.

strategy was performed (Fig. 1). C. necator mutant strain was cultivated in condition known to trigger PHB production. Since this mutant was unable to produce PHB we attempted to push the carbon flow toward acetyl-CoA, PHB precursor, to promote acyl$\mathrm{ACP}$ and alka(e)nes production. During nitrogen starvation culture, Re2061-pLC10 strain defective in PHB production produced mainly pyruvate as described by Steinbüchel and Schlegel (1989). This observation means that, in absence of PHB, unbalanced growth condition carry high carbon flow in Re2061-pLC10 strain. However in this condition alka(e)nes production was very low. As described for PHB production (Grousseau et al., 2013), by sustaining a controlled residual growth of $0.02 \mathrm{~h}^{-1}$ (nitrogen limitation fed-batch culture), the alka(e)nes specific production was improved 42 times (from $0.22 \mathrm{mg} / \mathrm{g}_{\mathrm{CDW}}$ to $9.36 \mathrm{mg} / \mathrm{g}_{\mathrm{CDW}}$ ).

In others studies on metabolic engineering of $C$. necator strain for fatty acid derivatives production, authors highlighted that $\beta$ oxidation system must be engineered to enhance production (Chen et al., 2015; Müller et al., 2013). In this study, we heterologously expressed cyanobacteria alka(e)ne pathway using acylACP precursor instead of free fatty acid or acyl-CoA. By this way, acyl-ACP was directly supported by alka(e)ne pathway enzyme, limiting free fatty acid or acyl-CoA in order to prevent $\beta$-oxidation activation. Indeed, we did not need to use $C$. necator strain deleted for $\beta$-oxidation to produce substantial alka(e)nes amount.

Extractive bi-phasic fermentation strategy using a decane organic phase was used in order to pull carbon flux toward alka(e)nes production. During the nitrogen starvation culture of Re2061-pLC10 decane increased 4 times the specific production of pentadecane (from $0.22 \pm 0.01 \mathrm{mg} / \mathrm{g}_{\mathrm{CDW}}$ to $0.94 \pm 0.33 \mathrm{mg} / \mathrm{g}_{\mathrm{CDW}}$ ). Whereas without decane, pentadecane was found both in supernatant and cell pellet, in presence of decane pentadecane was only detected in the decane phase. During the N-limited biphasic fed-batch, the addition of decane increased 2 times the total hydrocarbon production (from $9.58 \pm 0.49 \mathrm{mg} / \mathrm{g}_{\mathrm{CDW}}{ }^{-}$to $18.72 \pm 0.94 \mathrm{mg} / \mathrm{g}_{\mathrm{CDW}}$ respectively). In terms of carbon distribution, we showed that addition of decane strongly increased carbon flow toward alkanes and aldehydes production. Thereby addition of decane seems to improve secretion of alkanes produced into the supernatant leading to enhance global production by pulling carbon flux toward alkane pathway production. Extracellular alka(e)nes preferentially solubilize in the decane phase sustaining a concentration gradient favorable to alka(e)ne export out of the cells. While specific production 
rate of total products was strongly increased by addition of decane, we also showed that the maximum specific production rate of alkanes did not increase. Decane effect was mostly observed on aldehyde production suggesting that, in this condition, ADO activity was limiting at a value of around $1 \mu \mathrm{mol} \mathrm{g}_{\mathrm{CDW}}{ }^{-1} \mathrm{~h}^{-1}$. Furthermore the effective production of alka(e)enes in Re2061-pLC10 strain demonstrated that a $C$. necator endogenous ferredoxin and ferredoxin reductase_like activity was present and able to support S. elongatus ADO activity. Thus the ADO limitation could be due either to an insufficient expression of the ADO or of the ferredoxin and ferredoxin reductase endogenous system.

\subsection{AAR showed, in vivo, higher specificity towards C18 fatty acids}

Overall profile of alka(e)nes produced in absence of decane reflected the profile of fatty acid composition into the biomass excepted for palmitoleic acid (Fig. 6). Indeed for all fatty acids found in the biomass, the corresponding alka(e)nes were detected in similar proportion; $65 \%$ of palmitic acid for $75 \%$ of pentadecane, $12 \%$ of oleic acid for $20 \%$ of heptadecene, around $3 \%$ of myristic acid for $2 \%$ of tridecane. We also detected few heptadecane which can be associated with stearic acid transitory production at the beginning of nitrogen limited phase. In presence of decane, the same observation holds true taking into account that $45 \%$ of pentadecane and $35 \%$ hexadecanal were detected for $65 \%$ of palmitic acid and expected that no tridecane could be quantified. Our results are consistent with (Bi et al., 2013) where pentadecane and heptadecene were also produced with $C$. necator engineering strain. Moreover in other organisms alka(e)nes produced are mostly pentadecane, heptadecane and heptadecene. The calculated molar ratio between the specific production rates of alka(e) ne and the parent fatty acid showed the highest values for C17ane/C18:0 and C17-ene/C18:1 within a range of $[2,6]$ and $[2,4]$ respectively, compared to a ratio for $\mathrm{C} 15$-ane/C16:0 in the range of $[0.5,1]$. It suggested that AAR had higher in vivo specificity for C18:0 and C18:1. However $C$. necator strain contained more than $20 \%$ of palmitoleic acid and no pentadecene was produced. Absence of pentadecene production is in accordance with previous results obtained in E. coli (Schirmer et al., 2010). Overexpression of AAR from S. elongatus and ADO from Nostoc punctiforme into E. coli led to the production of hexadecenal and pentadecene, however pentadecene was not detected in the E.coli strain expressing the ADO from S. elongatus (Schirmer et al., 2010) meaning that AAR could react with palmitoleic acid to produce hexadecenal but only ADO from $N$. punctiforme could transform it into pentadecene.

\subsection{C. necator is an excellent candidate for alka(e)nes production from $\mathrm{CO}_{2}$ as sole $\mathrm{C}$-source}

First demonstration of alka(e)nes production by $C$. necator reached a final titer at $6 \mathrm{mg} / \mathrm{l}$ in rich media in batch with decane organic phase (Bi et al., 2013). In this study, we showed that thanks to deletion of the PHB pathway and culture condition optimization C. necator was able to produced up to $435 \mathrm{mg} / \mathrm{l}$ of alka (e)nes and $670 \mathrm{mg} / \mathrm{L}$ of total hydrocarbons and $18.7 \mathrm{mg} / \mathrm{g}_{\mathrm{CDW}}$ is the highest reported so far. Our results were competitive with actual reported works. Indeed, higher alka(e)nes production was obtained in an engineered $E$. coli where final alka(e)nes production titer was $581 \mathrm{mg} / \mathrm{l}$ (Choi and Lee, 2013). As a first attempt of demonstration of alka(e)ne production from $\mathrm{CO}_{2}$ by a non-native alka(e)ne producer, the $C$. necator strain Re2061-pLC10 was cultivated in a bioreactor fed with a gas mixture under $\mathrm{N}$ - and $\mathrm{O}_{2}$-limitation conditions upon addition of arabinose. Autotrophic conditions were not optimal since the gas mixture $\mathrm{H}_{2} / \mathrm{O}_{2} / \mathrm{CO}_{2}(60 /$ $2 / 10$ ) was far from the optimal stoichiometry for growth $(63 / 23 / 9)$ (Morinaga et al., 1978). $\mathrm{O}_{2}$-limitation was carried out to both avoid the explosion risk and restrict the inhibition of $C$. necator hydrogenases by $\mathrm{O}_{2}$ concentration. Decane was not added for safety reasons as well. However a final titer of $4.4 \mathrm{mg} / \mathrm{l}$ alka(e)nes was obtained in $56 \mathrm{~h}$. The non optimal autotrophic conditions accessible with our bioreactor design likely explained why the autotrophic level of alkane production $\left(0.8 \mathrm{mg} / \mathrm{g}_{\mathrm{CDW}}\right)$ was much lower compared to heterotrophic production $\left(9.6 \mathrm{mg} / \mathrm{g}_{\mathrm{CDW}}\right)$ in absence of organic phase. These performances could be easily improved within an optimal bioreactor dedicated for autotrophic conditions with better gas transfer capacity. Comparatively the native alkane producer Synechocystis sp. PCC6803 mutant strain reached a final titer of $26 \mathrm{mg} / \mathrm{l}$ alka(e)nes in 10 days from $\mathrm{CO}_{2}$ (Wang et al., 2013). All together this results demonstrated that $C$. necator is a very promising strain to produce alka(e)nes from $\mathrm{CO}_{2}$.

\section{Acknowledgements}

We thank A.J. Sinskey for providing us the Re2061 mutant strain. We also thank the A.J. Sinskey laboratory (MIT) for general technical advice. We are grateful to E. Grousseau and J. Marc for technical advice and helpful discussions. This work has benefited of the assistance from the French Research Ministry managed by the Agence Nationale de la Recherche under the program" Investissements d'Avenir "bearing the ANR-11-BTBR-0003 reference.

\section{References}

Aragao, G.M.F., Lindley, N.D., Uribelarrea, J.L., Pareilleux, A., 1996. Maintaining a controlled residual growth capacity increases the production of PHA copolymers by Alcaligenes eutrophus. Biotechnol. Lett. 18, 937-942. http://dx.doi.org/ 10.1007/BF00154625.

Atsumi, S., Wu, T.-Y., Eckl, E.-M., Hawkins, S.D., Buelter, T., Liao, J.C., 2010. Engineering the isobutanol biosynthetic pathway in Escherichia coli by comparison of three aldehyde reductase/alcohol dehydrogenase genes. Appl. Microbiol. Biotechnol. 85, 651-657. http://dx.doi.org/10.1007/s00253-009-2085-6.

Atsumi, S., Cann, A.F., Connor, M.R., Shen, C.R., Smith, K.M., Brynildsen, M.P., Chou, K.J.Y., Hanai, T., Liao, J.C., 2008. Metabolic engineering of Escherichia coli for 1-butanol production. Metab. Eng. 10, 305-311. http://dx.doi.org/10.1016/j. ymben.2007.08.003.

Beller, H.R., Lee, T.S., Katz, L., 2015. Natural products as biofuels and bio-based chemicals: fatty acids and isoprenoids. Nat. Prod. Rep. 00, 1-19. http://dx.doi. org/10.1039/C5NP00068H.

Bi, C., Su, P., Müller, J., Yeh, Y.-C., Chhabra, S.R., Beller, H.R., Singer, S.W., Hillson, N.J., 2013. Development of a broad-host synthetic biology toolbox for Ralstonia eutropha and its application to engineering hydrocarbon biofuel production. Microb. Cell Fact. 12, 107. http://dx.doi.org/10.1186/1475-2859-12-107.

Buijs, N. a, Zhou, Y.J., Siewers, V., Nielsen, J., 2015. Long-chain alkane production by the yeast Saccharomyces cerevisiae. Biotechnol. Bioeng. 112, 1275-1279. http: //dx.doi.org/10.1002/bit.25522.

Chen, G.-Q., 2009. A microbial polyhydroxyalkanoates (PHA) based bio- and materials industry. Chem. Soc. Rev. 38, 2434-2446. http://dx.doi.org/10.1039/ b812677c.

Chen, J.S., Torella, J.P., Colon, B., Dusel, B., Ziesack, M., Way, J.C., Silver, P.A., 2015 Production of fatty acids in Ralstonia eutropha $\mathrm{H} 16$ by engineering beta-oxidation and carbon storage. PeerJ, 1-24. http://dx.doi.org/10.7717/peerj.1468.

Choi, Y.J., Lee, S.Y., 2013. Microbial production of short-chain alkanes. Nature 502, 571-574. http://dx.doi.org/10.1038/nature12536.

Cracknell, J.A., Wait, A.F., Lenz, O., Friedrich, B., Armstrong, F.A., 2009. A kinetic and thermodynamic understanding of $\mathrm{O}_{2}$ tolerance in [NiFe]-hydrogenases. Proc. Natl. Acad. Sci. USA 106, 20681-20686. http://dx.doi.org/10.1073/ pnas.0905959106.

Fukui, T., Ohsawa, K., Mifune, J., Orita, I., Nakamura, S., 2011. Evaluation of promoters for gene expression in polyhydroxyalkanoate-producing Cupriavidus necator H16. Appl. Microbiol. Biotechnol. 89, 1527-1536. http://dx.doi.org/ 10.1007/s00253-011-3100-2.

Gibson, D.G., Young, L., Chuang, R., Venter, J.C., Iii, C.A.H., Smith, H.O., America, N., 2009. Enzymatic assembly of DNA molecules up to several hundred kilobases. Nat. Methods 6, 341-347. http://dx.doi.org/10.1038/NMETH.1318.

Grousseau, E., Lu, J., Gorret, N., Guillouet, S.E., Sinskey, A.J., 2014. Isopropanol production with engineered Cupriavidus necator as bioproduction platform. Appl. Microbiol. Biotechnol. 98, 4277-4290. http://dx.doi.org/10.1007/ s00253-014-5591-0.

Grousseau, E., Blanchet, E., Déléris, S., Albuquerque, M.G.E., Paul, E., Uribelarrea, J.L., 2013. Impact of sustaining a controlled residual growth on polyhydroxybutyrate yield and production kinetics in Cupriavidus necator. 
Bioresour. Technol. 148, 30-38. http://dx.doi.org/10.1016/j.biortech.2013.08.120. Insomphun, C., Mifune, J., Orita, I., Numata, K., Nakamura, S., Fukui, T., 2014 Modification of $\beta$-oxidation pathway in Ralstonia eutropha for production of poly(3-hydroxybutyrate-co-3-hydroxyhexanoate) from soybean oil. J. Biosci. Bioeng. 117, 184-190. http://dx.doi.org/10.1016/j.jbiosc.2013.07.016.

Insomphun, C., Xie, H., Mifune, J., Kawashima, Y., Orita, I., Nakamura, S., Fukui, T., 2015. Improved artificial pathway for biosynthesis of poly(3-hydroxybutyrateco-3-hydroxyhexanoate) with high C6-monomer composition from fructose in Ralstonia eutropha. Metab. Eng. 27, 38-45. http://dx.doi.org/10.1016/j. ymben.2014.10.006.

Islam Mozumder, M.S., Garcia-Gonzalez, L., Wever, H., De, Volcke, E.I.P., 2015. Poly (3-hydroxybutyrate) (PHB) production from $\mathrm{CO}_{2}$ : model development and process optimization. Biochem. Eng. J. 98, 107-116. http://dx.doi.org/10.1016/j. bej.2015.02.031.

Ladygina, N., Dedyukhina, E.G., Vainshtein, M.B., 2006. A review on microbial synthesis of hydrocarbons. Process Biochem. 41, 1001-1014. http://dx.doi.org/ 10.1016/j.procbio.2005.12.007.

Li, H., Opgenorth, P.H., Wernick, D.G., Rogers, S., Wu, T.-Y., Higashide, W., Malati, P., Huo, J.C., Cho, K.M., Liao, J.C., 2012. Integrated electromicrobial conversion of $\mathrm{CO}_{2}$ to higher alcohols. Science 335, 1596. http://dx.doi.org/10.1126/ science.1217643.

Li, N., Chang, W.-C., Warui, D.M., Booker, S.J., Krebs, C., Bollinger, J.M., 2012. Evidence for only oxygenative cleavage of aldehydes to alk(a/e)nes and formate by cyanobacterial aldehyde decarbonylases. Biochemistry 51, 7908-7916. http: //dx.doi.org/10.1021/bi300912n.

Lu, J., Brigham, C.J., Gai, C.S., Sinskey, A.J., 2012. Studies on the production of branched-chain alcohols in engineered Ralstonia eutropha. Appl. Microbiol. Biotechnol. 96, 283-297. http://dx.doi.org/10.1007/s00253-012-4320-9.

Müller, J., MacEachran, D., Burd, H., Sathitsuksanoh, N., Bi, C., Yeh, Y.-C., Lee, T.S., Hillson, N.J., Chhabra, S.R., Singer, S.W., Beller, H.R., 2013. Engineering of Ralstonia eutropha $\mathrm{H} 16$ for autotrophic and heterotrophic production of methyl ketones. Appl. Environ. Microbiol. 79, 4433-4439. http://dx.doi.org/10.1128/ AEM.00973-13.

Morinaga, Y., Yamanaka, S., Ishizaki, A., Hirose, Y., 1978. Growth characteristics and cell composition of Alcaligenes eutrophus in chemostat culture. Agric. Biol. Chem. 42, 439-444.

Peralta-Yahya, P.P., Zhang, F., del Cardayre, S.B., Keasling, J.D., 2012. Microbial engineering for the production of advanced biofuels. Nature 488, 320-328. http: //dx.doi.org/10.1038/nature11478.

Pohlmann, A., Fricke, W.F., Reinecke, F., Kusian, B., Liesegang, H., Cramm, R., Eitinger, T., Ewering, C., Pötter, M., Schwartz, E., Strittmatter, A., Voss, I., Gottschalk, G., Steinbüchel, A., Friedrich, B., Bowien, B., 2006. Genome sequence of the bioplastic-producing "Knallgas" bacterium Ralstonia eutropha H16. Nat. Biotechnol. 24, 1257-1262. http://dx.doi.org/10.1038/nbt1244.
Reinecke, F., Steinbüchel, A., 2009. Ralstonia eutropha Strain H16 as model organism for PHA metabolism and for biotechnological production of technically interesting biopolymers. J. Mol. Microbiol. Biotechnol. 16, 91-108. http://dx.doi.org/ $10.1159 / 000142897$.

Reppas, N.B., Ridley, C.P., 2010. Methods and compositions for the recombinant biosynthesis of n-alkanes. US7794969.

Schirmer, A., Rude, M.a., Li, X., Popova, E., delCardayre, S.B., 2010. Microbial biosynthesis of alkanes. Science 329, 559-562. http://dx.doi.org/10.1126/ science.1187936.

Schuster, E., Schlegel, H.G., 1967. Chemolithotrophic growth of Hydrogenomonas H16 in a chemostat with electrolytic production of oxygen and hydrogen. Arch. Mikrobiol. 58, 380-409.

Sheppard, M.J., Kunjapur, A.M., Prather, K.L.J., 2015. Modular and selective biosynthesis of gasoline-range alkanes. Metab. Eng. 33, 28-40. http://dx.doi.org/ 10.1016/j.ymben.2015.10.010.

Siegel, R.S., Ollis, D.F., 1984. Kinetics of growth of the hydrogen-oxidizing bacterium Alcaligenes eutrophus (ATCC-17707) in chemostat culture. Biotechnol. Bioeng. 26, 764-770.

Steinbüchel, A., Schlegel, H.G., 1989. Excretion of pyruvate by mutants of Alcaligenes eutrophus, which are impaired in the accumulation of poly(beta-hydroxybutyric acid) (PHB), under conditions permitting synthesis of PHB. Appl. Microbiol. Biotechnol. 31, 168-175. http://dx.doi.org/10.1007/BF00262457.

Stothard, P., Van Domselaar, G., Shrivastava, S., Guo, A., O'Neill, B., Cruz, J., Ellison, M., Wishart, D.S., 2005. BacMap: An interactive picture atlas of annotated bacterial genomes. Nucleic Acids Res. 33, 317-320. http://dx.doi.org/10.1093/ nar/gki075.

Tanaka, K., Ishizaki, A., Kanamaru, T., Kawano, T., 1995. Production of poly (D-3hydroxybutyrate) from $\mathrm{CO}_{2}, \mathrm{H}_{2}$, and $\mathrm{O}_{2}$ by high cell density autotrophic cultivation of Alcaligenes eutrophus. Biotechnol. Bioeng. 45, 268-275.

Torella, J.P., Gagliardi, C.J., Chen, J.S., Bediako, D.K., Colón, B., Way, J.C., Silver, P.A., Nocera, D.G., 2015. Efficient solar-to-fuels production from a hybrid microbialwater-splitting catalyst system. Proc. Natl. Acad. Sci. YSA 112, 201503606. http: //dx.doi.org/10.1073/pnas.1503606112.

Wang, W., Lu, X., 2013. Microbial synthesis of alka(e)nes. Front. Bioeng. Biotechnol. 1, 1-5. http://dx.doi.org/10.3389/fbioe.2013.00010.

Wang, W., Liu, X., Lu, X., 2013. Engineering cyanobacteria to improve photosynthetic production of alka(e)nes. Biotechnol. Biofuels 6, 69. http://dx.doi.org/ 10.1186/1754-6834-6-69.

Warui, D.M., Li, N., Nørgaard, H., Krebs, C., Bollinger Jr., J.M., Booker, S.J., 2011. Detection of formate, rather than carbon monoxide, as the stoichiometric coproduct in conversion of fatty aldehydes to alkanes by a cyanobacterial aldehyde decarbonylase. J. Am. Chem. Soc. 133, 3316-3319. http://dx.doi.org/ $10.1021 /$ ja111607x 